\title{
The Relationship between Hotel Rating and Customer Outcomes and Its Implication towards Revisit Intention
}

\author{
Suresh Kumar ${ }^{1}$ and Miftah Zikri ${ }^{2}$ \\ Department Management, Faculty of Business, President University \\ Jl. Ki Hajar Dewantara, Kota Jababeka, Cikarang Baru, Bekasi 17550, Indonesia \\ Email: sureshkumar@president.ac.id; miftah.zikri@president.ac.id
}

\begin{abstract}
This research aims to examine HOLSERV with three dimensions namely, employee, tangible and reliability, towards its relationship on customer satisfaction and return intention rather than SERVQUAL because it suits hotel environment. The object analysis was Bandung which proclaimed herself as a tourism city with quiet number of hotels rating as non-star to five-star hotels. From 41 three-star hotels, this research managed to cover 29 hotels to conduct this research. Respondents with total number of 355 participated to fill the questionnaire with the helped of hotel managers by spreading it to their customers who were checking out of the hotel. Structural equation modeling was applied to test the hypothesis and the results show that tangibility and reliability influence customers' satisfaction but not employee. In addition, customer satisfaction influences return intention.
\end{abstract}

Keywords HOLSERV, SERVQUAL, Rating, Satisfaction, Return Intention

\begin{abstract}
Abstrak
Penelitian ini bertujuan untuk menguji HOLSERV dengan tiga dimensi yaitu, karyawan, berwujud dan reliabilitas, karena lingkungan hotelnya yang sesuai. Analisis objek adalah Bandung yang menyatakan dirinya sebagai kota pariwisata dengan sejumlah hotel bintang. Dari 41 hotel bintang tiga, penelitian ini berhasil mencakup 29 hotel untuk melakukan penelitian ini. Responden dengan jumlah total 355 berpartisipasi untuk mengisi kuesioner dengan bantuan manajer hotel dengan menyebarkannya ke pelanggan mereka yang sedang check-out dari hotel. Pemodelan persamaan struktural diterapkan untuk menguji hipotesis dan hasilnya menunjukkan bahwa tangibilitas dan keandalan mempengaruhi kepuasan pelanggan tetapi bukan karyawan. Selain itu, kepuasan pelanggan mempengaruhi niat kembali.
\end{abstract}

Kata kunci: HOLSERV, SERVQUAL, Rating, Kepuasan, Intensi Kembali 


\section{A. Introduction}

A routine life causes boredom, stress, and ultimately leads to health problems. For that, it needs a way to release it and one such way is by taking a vacation. Hence, it flourishes tourism spots as recorded by United Nation World Trade Organization (UNWTO, 2015) that the tourism industry has grown very fast and large and contributes to $9 \%$ of the world's Gross Domestic Product. Not only that, further research from the UNWTO on the labor supply side shows that the world of tourism contributes 1 out of 11 world workers with total exports USD 1.5 trillion. The results also show an increasing trend of increasing international tourist numbers to 1.134 billion tourists in 2015 and five to six billion domestic tourists. It is also predicted that international tourists will rise up to 1.8 billion tourists in 2020 .

With the potential of both international and national tourists, certainly make governments in developing and developed countries are competing to introduce the beauty of their respective countries. For example we can see Malaysia with its tag line, Truly Asia; Indonesia, Wonderful Indonesia; Singapore, New Asia Singapore: So easy to enjoy, so hard to forget; China, Beautiful China: China Like Never Before, and Thailand, Amazing Thailand: It begins with the people. For the Southeast Asia region, Thailand is among the best where the UNWTO survey results put it as rank 9 out of 10 worlds for the category of countries where tourists spend a lot of money (USD 38.4 billion) by 2014. However, judging by the number of visitors to Southeast Asia, Malaysia is still the champion with 27.437 million tourists followed by Thailand (24.780 million), Singapore (11.868 million) and Indonesia (9.436 million). In Indonesia alone, the most visited place by tourists are Bali followed by Jakarta, Riau Islands, North Sumatra, East Java, West Java, Jogjakarta, West Nusa Tenggara, West Sumatra and Riau (Statistics Indonesia, 2015). One of the cities that became a tourist destination in West Java is the city of Bandung. Bandung Municipality provides the supporting facilities like restaurants (733 units), cafes (13 units), bars (13 units), art galeries (27), theatres (13), museums (7), historical buildings (371), golf (1 unit), 5-star hotels (9 units), 4-star hotels (32 units), 3-star hotels (41), 2-star hotels (25), 1-star hotels (10 units), non-star hotels (275 units) and others. Hence, the tourism sector, from those facilities so far, contributes approximately 35\% for its regional income (Bandung City in Figure, 2016). Thus, it is very important for these hotels to have a good rating to ensure return intention of their customers. Especially Bandung Municipality which despite having so many tourism potentials but still not able to shift the position of Bali as the most visited place or even Jakarta eventhough it is on the border of Bandung

A research conducted by Huertas-Garcia, Garcia, and Consolacion (2014) found that the page size of advertisement, hotel rating, price affects the selection of hotels from customers. Another Research conducted by Felix and Clever (2014) conducted in Zimbabwe have also found that there is a positive relationship between hotel rating, service quality and customer satisfaction. It is also found that service delivery and customer satisfaction can improve the revisit intention (Adesina and Chinonso, 2015). Similarly, presented by research conducted by Tefera and Govender (2014), expectations of service quality towards hotel grading (hotel rating), perceptions of service quality towards hotel grading, service satisfaction associated with hotel grading, customer loyalty associated with hotel grading, hence hotel grading is associated with customer expectations of service quality, service quality perceptions, satisfaction and loyalty. But, less research has been found using HOLSERV as a replacement 
to service quality in hotel industry (Mei, Dean \& White, 1999). Thus, this research contributes on the empirical findings of HOLSERV and its relations towards satisfaction and indirectly to revisit intention in Indonesia

Hence, this research aims to examine the Relationship between Hotel Rating and Customer Outcomes and Its Implication towards Revisit Intention. This research presents a literature review on hotel rating, HOLSERV, satisfaction and revisit intention. Furthermore, the research methods, including: sampling and data collection; measurement of the constructs and data analysis techniques, are discussed. Structural equation model is applied to test the hypothesis based on the research aims. Last but not least, future recommendations based on the research findings for practitioners and future researchers are provided.

\section{B. Literature Review}

\subsection{Hotel Rating}

A hotel is a building where we have to pay to get a room to sleep, and a place where you occasionally eat (dictionary.cambridge.org). A hotel is defined as a place that provides accommodation, food and other services for tourists and tourists alike (oxforddictionaries.com). A hotel is also defined as a form of commercially administered accommodation, which is provided for everyone to obtain the following services and lodging for meals and drinks (Decree of the Minister of Transportation of Indonesia no. PM. 10 / PW.301 / Phb.77). It is then refined through as a company providing services in the form of accommodation as well as providing dishes and other facilities within the hotel to the public and eligible for convenience and for commercial purposes in such services (Decree of the Minister of Transportation of Indonesia No. 241/11/1970).

Hotel Rating or classification of hotels is the grouping of hotels into various classes or levels based on a particular assessment. And in accordance with the Decree of the Minister of Transportation of Indonesia no. PM. 10 / PW. 301 / Pdb - 77, the hotel is classified based on the number of mattresses, facilities, equipment available and the quality of service. Hotels are classified into five classes of hotels ie 1 to 5 star (Decree of the Minister of Transportation of Indonesia: Kep-22 / U / VI / 78). The classification of the hotel becomes important because the classification informs about the facilities provided and the quality of services to be obtained as well as the pricing so as to facilitate the prospective customers to choose the hotel they want (Whitelaw and Jago, 2009). In addition to customer convenience, the classification system is also beneficial for travel agents, tour operators, hotel industries, government (WTO \& IH \& RA, 2004). The results of Shahril, Aziz, Othman and Bojer (2015) also show that hotel rating has relationship towards service guarantee and customer satisfaction.

\subsection{Hotel Service Quality}

Service Quality has become the standard measurement in service industries for satisfaction. Starting from the research of Parasuraman et al since 1985, SERVQUAL is still valid and reliable today despite adjustments for different fields. For example, DINESERVE is a service quality measurement for restaurants based on the results of the study of Stevens, Knutson and Patton (1995). In the banking sector, there is SERVPERF by Cronin and Taylor (1992). LODGSERV is used to measure the services of lodging houses (LODGE) based on research by Knutson et al (1992), whereas HOLSERV is used to measure services at a hotel (May, Dean \& White, 1999; Nguyen, Nguyen, Phan and Matsui, 2015). RSQS (Retail Service 
Quality Scale) is developed by Dabholkar (1996) and used in retail sector. All these researches indicate that SERVQUAL still shows the drivers of customer satisfaction. In this research, however, HOLSERV model is used instead of the original SERVQUAL dimensions to examine its influence on customer satisfaction and also revisit intention. The dimensions of HOLSERV are based on the work of Mei, Dean \& White (1999) which consists of three parts, namely employees, tangible, and reliability.

\subsection{Revisit Intention}

The survival of a hotel is certainly without doubt depend on its customers. Since it is too expensive to find out new customers, hence it is better to retain existing customers and re-use the hotel services in the future (Gallo, 2014). The desire to return and use the services of the hotel is again influenced by the customer's satisfaction by the services provided (Berezan et al., 2013). Similarly, research conducted by Tussyadiah (2016) found that the desire to return to the hotel is influenced by guest satisfaction based on their experiences using the services of the peer-to-peer accommodation especially enjoyment and value. In addition, Ali (2015) found that the quality of service has a significant effect on the desire to re-use the hotel services in the future.

Furthermore, Fakharyan et al. (2014) and Ali and Amin (2014) found that satisfaction of service impacts not only the desire to return but also the desire to spread word of mouth (Kitapci, Akdogan and Dortyol, 2014) and at the end become loyal customers of the hotel (Liat, Mansori and Huei, 2014).

\subsection{Theoretical Framework}


Figure 1. Theoretical Framework

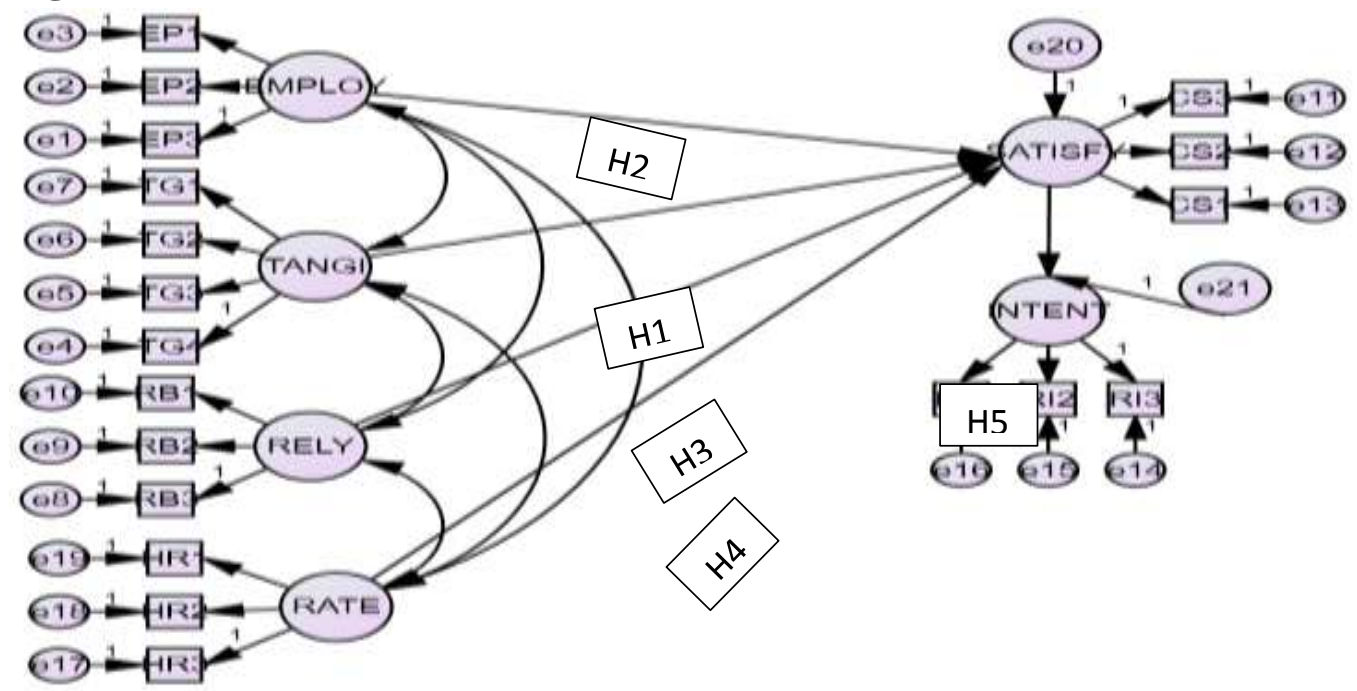

\section{Hypotheses:}

H1: Tangible influence Customer Satisfaction

H2: Employee influence Customer Satisfaction

H3: Reliability influence Customer Satisfaction

H4: Hotel Rating influence Customer Satisfaction

H5: Customer Satisfaction influence Revisit Intention

\section{Methods}

This research applied a quantitative research with survey as the instrument. This research aimed at people who experienced in staying in three stars hotel in Bandung. This research was conducted on $10^{\text {th }}$ May until $25^{\text {th }}$ July 2017 with the total number of respondents were 355 respondents (Table 1).

The number of female is more than half of all respondents, which is 64\% (226 persons), whereas the number of male is only $36 \%$ (129 persons). The respondents are mostly between $17-23$ years old ( 287 persons) followed by age between $24-29$ years old (36 persons), age between 30 - 35 years old ( 20 persons) and the rest are more than 35 years old (12 persons). From the occupation, most of the respondents are students (266 students) followed by employee (43 employees), entrepreneurs (27 persons) and others are unspecified (12 persons). From the income point, mostly between IDR 1,000,000 - IDR 3,000,000 (166 persons) followed by less than IDR 1,000,000 (77 persons), between IDR 3,000,000 - IDR $6,000,000$ (73 persons), between IDR 6,000,000 - IDR 10,000,000 (21 persons) and more than IDR 10,000,000 (18 persons). 
Table 1. Respondents' Profile

\section{Gender}

Male

Female

Age

$17-23$ years old

$24-29$ years old

$30-35$ years old

$>35$ years old

\section{Occupation}

Student

Employee

Entrepreneur

Others

Income

$<\mathrm{Rp} 1,000,000$

Rp1,000,000 - Rp3,000,000

Rp3,000,000 - Rp6,000,000

Rp6,000,000 - Rp10,000,000

$>$ Rp10,000,000

\section{Percentage}

$36 \%$

$64 \%$

Percentage

$81 \%$

$10 \%$

$6 \%$

$3 \%$

\section{Percentage}

$76 \%$

$12 \%$

$8 \%$

$4 \%$

\section{Percentage}

$21 \%$

$47 \%$

$21 \%$

$6 \%$

$5 \%$

The research covered most of the 3-star hotels, 29 out of 41 hotels with the ranging participants of $2 \%$ up to $7 \%$ ( Fave and Santika Hotel). With the help of the hotel managers, the questionnaires were distributed to customers who were checking out from the hotel.

Table 2. List of Hotels

\begin{tabular}{|l|l|l|}
\hline No & Hotels Name & Percentage \\
\hline 1 & Kedaton Hotel & $4 \%$ \\
\hline 2 & Summer Hill Family Hotel & $4 \%$ \\
\hline
\end{tabular}




\begin{tabular}{|l|l|l|}
\hline 3 & The Summit Siliwangi Hotel & $4 \%$ \\
\hline 4 & Sapulidi Hotel & $3 \%$ \\
\hline 5 & Simply Valore Hotel & $5 \%$ \\
\hline 6 & Grand Malabar Hotel & $4 \%$ \\
\hline 7 & Selera Merdeka Hotel & $4 \%$ \\
\hline 8 & NEO Bandung & $3 \%$ \\
\hline 9 & Grand Paradise Hotel & $5 \%$ \\
\hline 10 & Serela Hotel & $3 \%$ \\
\hline 11 & Nalendra Bandung Hotel & $4 \%$ \\
\hline 12 & Enhaii Hotel & $3 \%$ \\
\hline 13 & Asmila Boutique Hotel Bandung & $4 \%$ \\
\hline 14 & MaxOneHotels Bandung & $3 \%$ \\
\hline 15 & Hotel California Bandung & $4 \%$ \\
\hline 16 & Meize Hotel Bandung & $3 \%$ \\
\hline 17 & Hotel Mitra Bandung & $3 \%$ \\
\hline 18 & BTC Hotel & $3 \%$ \\
\hline 19 & the Newton Hotel & $3 \&$ \\
\hline 20 & Gumilang Regency Hotel & $3 \%$ \\
\hline 21 & Bali World Hotel & $3 \%$ \\
\hline 22 & Favehotel Bandung & $7 \%$ \\
\hline 23 & Hotel Santika Bandung & $7 \%$ \\
\hline 24 & Fabu Hotel Bandung & $3 \%$ \\
\hline 25 & PROMENADE Hotel & $3 \%$ \\
\hline 26 & the Peak Home Boutique Hotel & $3 \%$ \\
\hline 27 & V Hotel & $2 \%$ \\
\hline 28 & Hotel Vio & $3 \%$ \\
\hline 29 & The Palais Dago & $3 \%$ \\
\hline & & \\
\hline & & $3 \%$ \\
\hline
\end{tabular}

\section{Findings and Discussions}

Before testing the hypothesis, the adequacy of each multi-item scale measuring each variable or construct was assessed for its construct validity (convergent and discriminant validity) and reliability (Hair et al, 2010). The factor loadings for all items were above 0.44 or less with more than 150 samples as suggested by Malhotra (2010), hence all the items passed the minimum criteria except for item TG1 (0.428) which was slightly less than 0.44 (Table 3). As for the reliability test, all items were reliable since they were above 0.6 (ranging 0.612 to $0.713)$.

Table 3. Validity and Reliability Test

$\begin{array}{lllllll}\text { Factor } & \text { Variable } & \text { Question } & \text { Mean } & \begin{array}{l}\text { Standard } \\ \text { Deviation }\end{array} & \begin{array}{l}\text { Factor } \\ \text { Loading }\end{array} & \text { Cronbach's } \\ & & & & & \text { Alpha }\end{array}$




\begin{tabular}{|c|c|c|c|c|c|c|}
\hline \multirow{2}{*}{$\begin{array}{l}\text { Hotel } \\
\text { Rating }\end{array}$} & & HR1 & 4.96 & 1.59 & 0.810 & \multirow[b]{2}{*}{0.617} \\
\hline & & HR2 & 4.92 & 1.51 & 0.803 & \\
\hline & & HR3 & 5.24 & 1.45 & 0.504 & \\
\hline & \multirow[t]{3}{*}{ Employee } & EP1 & 5.34 & 1.41 & 0.768 & \\
\hline & & EP2 & 5.31 & 1.45 & 0.859 & 0.713 \\
\hline & & EP3 & 5.30 & 1.41 & 0.591 & \\
\hline \multirow[t]{7}{*}{ HOLSERV } & \multirow[t]{4}{*}{ Tangible } & TG1 & 5.07 & 1.39 & 0.428 & \\
\hline & & TG2 & 5.11 & 1.47 & 0.778 & \\
\hline & & TG3 & 5.13 & 1.50 & 0.710 & 0.651 \\
\hline & & TG4 & 5.19 & 1.49 & 0.521 & \\
\hline & \multirow[t]{3}{*}{ Reliability } & RB1 & 5.00 & 1.53 & 0.606 & \\
\hline & & RB2 & 5.09 & 1.433 & 0.729 & 0.709 \\
\hline & & RB3 & 5.15 & 1.45 & 0.793 & \\
\hline Customer & & CS1 & 4.99 & 1.51 & 0.542 & \\
\hline \multirow[t]{2}{*}{ Satisfaction } & & $\mathrm{CS} 2$ & 5.18 & 1.46 & 0.741 & \multirow[t]{2}{*}{0.693} \\
\hline & & CS3 & 4.94 & 1.51 & 0.679 & \\
\hline Revisit & & RI1 & 5.06 & 1.38 & 0.801 & \multirow{3}{*}{0.612} \\
\hline \multirow[t]{2}{*}{ Intention } & & RI2 & 5.21 & 1.42 & 0.514 & \\
\hline & & RI3 & 5.13 & 1.49 & 0.736 & \\
\hline
\end{tabular}

As for data analysis Structural Equation Modelling was applied (Figure 1) to find out the model fit before testing the hypothesis. As the criteria mention by Hair et al (2010), the model is fit to be further analyze for the hypothesis testing (Table 4). From the first attempt, the model had CMIN/DF of 2.806, GFI of 0.901, IFI of 0.857 and RMSEA of 0.071 which means they met the minimum required except for AGFI (0.862), TLI (0.818), CFI (0.854), and NFI (0.794). The second attempt was conducted and the result was all the goodness of fit measures have increased to an acceptable minimum requirement except for TLI (0.887) and AGFI (0.891) which was very closed to the minimum requirement and considered mediocre (Table 4). Thus, this model was good fit to go for further analysis on the hypotheses testing.

Table 4. Result of Model Fit of SEM 
Goodness of Fit Measure

CMIN/DF

Goodness of fit index

Adjusted of goodness of fit index

Incremental Fit Index

Tucker Lewis Index

Comparative Fit Index

Normed Fit Index

Root Mean Square

Approximation

\section{Cut of Value}

$\mathrm{CMIN} / \mathrm{DF} \leq 5.00$

GFI $>0.9$

AGFI $>0.9$

IFI $>0.8$

TLI $>0.90$

$0<\mathrm{CFI}<1 \mathrm{CFI} \geq 0.900 .854$

0.794

$\mathrm{NFI}>0.80$

0.856

0.056

The customers of 3-star hotel in Bandung prefer the most is Reliability (Table 5). It is more to the special attention, knowledgeable staff and accurate record, hence hypothesis 3 which is reliability influences customer satisfaction is supported $(\beta=0.445, p<0.05)$. The second aspect that the customers prefer is the tangible aspect such as modern look equipment, adequate capacity, comfortable atmosphere and materials provided in the room should be adequate, hence the first hypothesis which is tangible influences customer satisfaction is supported $(\beta=0.316, p<0.05)$. It seems the 3 -star hotel rating does not give enough impact on customer satisfaction as it shows for 4-star and 5-star hotel (Shahril, Aziz, Othman, and, Bojei, 2015). From the hypothesis 4 testing it shows that hotel rating did not influence customer satisfaction $(\beta=0.049, \mathrm{p}>0.05)$. As it is also seen for hypothesis 2 that shows employee does not give influence to customer satisfaction $(\beta=0.128, p>0.05)$.

\section{Figure 2. Structural Equation Modelling Result}




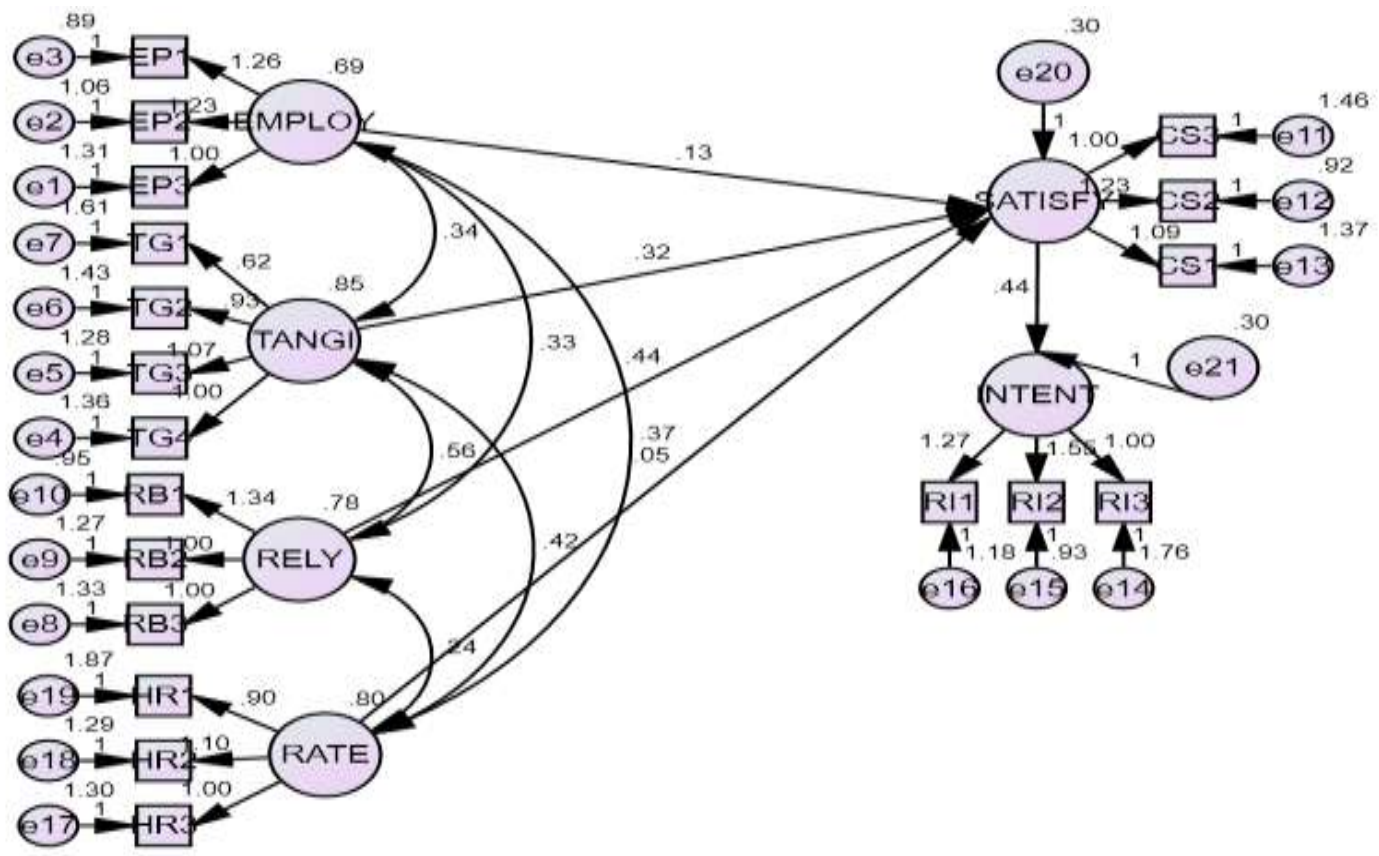

Table 5. Hypothesis Testing

\begin{tabular}{|ll|l|l|l|}
\hline Hypotheses & $\begin{array}{l}\text { Path } \\
\text { Coefficient }\end{array}$ & p-values & Results \\
\hline $\begin{array}{l}\text { H1: Tangible influence Customer } \\
\text { Satisfaction }\end{array}$ & 0.316 & 0.012 & Supported \\
\hline $\begin{array}{l}\text { H2: Employee influence Customer } \\
\text { Satisfaction }\end{array}$ & 0.128 & 0.151 & Not Supported \\
\hline $\begin{array}{l}\text { H3: Reliability influence Customer } \\
\text { Satisfaction }\end{array}$ & 0.445 & 0.001 & Supported \\
\hline $\begin{array}{l}\text { H4: Hotel Rating influence Customer } \\
\text { Satisfaction }\end{array}$ & 0.049 & 0.603 & Not Supported \\
\hline $\begin{array}{l}\text { H5: Customer Satisfaction influence Revisit } \\
\text { Intention }\end{array}$ & 0.443 & 0.001 & Supported \\
\hline
\end{tabular}

In general, customers do not really consider the grooming of the employee too much since it is also the same condition whenever you go to any 3 -star hotel that employees should wear a certain uniform. As for the willingness to serve, the customers believe that 3-star hotel is not that big that they would get lost or really need it something from the employees, hence they can do self-service rather than asking help from the employees. Employee should be polite is a must where ever you go especially for Asians politeness is belong to their culture. Hence, they do not see this as something extraordinary but it is part of their culture. For hypothesis 4 which is customer satisfaction influences return intention is supported $(\beta=0.443, p<0.05)$ which is inline with previous research (Gallo, 2014; Berezan et al., 2013; Tussyadiah, 2016; Liat, Mansori and Huei, 2014).

\section{E. Conclusion and Future Recommendation}

Bandung has hotels ranging from non-star to five-star hotels since Bandung has proclaimed itself as a tourism city. Looking at the number of 3-star hotels let many people who are 
looking at cheaper price hotel feel comfortable to choose. Their experiences staying in a 3star hotel have made the customers somehow realize the standard facilities given. On the other hand, as Asians being polite or showing hospitality is part of our life, hence employees showing their hospitality are necessary. Though the result showed it did not support the customer satisfaction but it has to be there and 3-star hotels need to show other thing to attract more customers to choose their hotel. Being with a family for a holiday, it is like moving our things from home to a hotel. Even though a hotel did not provide things needed in the bathroom like shampoo, soap etc., it does not bother at all. Nevertheless, for those people who are traveling alone or with friends, facilities such as things in the bathroom are very necessary. Staff in the hotel needs to be knowledgeable and give extra attention. All these lead to satisfaction and to be chosen when customers return to Bandung again for their staying purposes.

For researchers, HOLSERV provides suitable dimensions rather than SERVQUAL. However, it needs to be examines in other hotel rating or the same 3-star hotel but in different places especially in 10 new places which government of Indonesia has proclaimed as new destination for tourism.

\section{F. Acknowledgement}

This research paper was supported by Ministry of Research, Technology and Higher Education of the Republic of Indonesia based on the decree No. 025/E3/2017 on $6^{\text {th }}$ January 2017 Subject to the Announcement of the Result of Receiver Funding Research and Community Service in Higher Education Year 2017 and President University.

\section{G. References}

Adesina, K. I., and Chinonso, I. (2015). Service Delivery and Customer Satisfaction in hospitality industry: A study of the Divine Fountain Hotels Limited, Lagos, Nigeria. Journal of Hospitality and Management Tourism. Vol. 6. Iss: 1. pp. 1-7.

Ali, F., and Amin, M. (2014). The influence of physical environment on emotions, customer satisfaction and behavioral intentions in Chinese resort hotel industry. Journal for Global Business Advancement. Vol. 7. Iss. 3. Pp. 181-266.

Ali, F. (2015). Service Quality as a determinant of customer satisfaction and resulting behavioural intentions: A SEM approach towards Malaysian resort hotels. Turizam : medunarodni znanstveno-strucni casopis. Vol. 63. No. 1. Retrieved from http://hrcak.srce.hr/137482

Cronin Joseph Jr J, Taylor S (1992). "Measuring Service Quality: A Reexamination and Extension," J. Mark., Vol. 58

Berezan, O., Raab, C., Yoo, M., Love, C. (2013). Sustainable hotel practices and nationality: The impact on guest satisfaction and guest intention to return. International Journal of Hospitality Management. Vol. 34. Pp. 227-233.

Cronin, Jr J., Taylor. S. (1992). Measuring Service Quality: A Reexamination and Extension. Journal of Marketing., Vol. 56, No. 3 (Jul., 1992), pp. 55-68. 
Felix, C., Clever, V. (2014). The Relationship between Hotel Rating and Customer Outcomes: Customer Perceived Service Quality and Customer Satisfaction. Greener Journal of Business and Management Studies. Vol. 4. Iss: 4. pp. 146-152.

Fakharyan, M., Omidvar, S., Khodadadian, M .R., Jalilvand, M. R., Vosta, L. N. (2014). Examining the effect of Customer-to-Customer Interactions on Satisfaction, Loyalty, and Word-of-Mouth Behaviors in the Hospitality Industry: The Mediating Role of Personal Interaction Quality and Service Atmospherics. Journal of Travel \& Tourism Marketing. Vol. 31. Iss. 5. Pp. 610-626.

Gallo, M. (2014). The Value of Keeping the Right Customer. Retrieved from https://hbr.org/2014/10/the-value-of-keeping-the-right-customers on August 2016.

Huertas-Garcia, R., Garcia, M.L., and Consolacion, C. (2014). Conjoint Analysis of Tourist Choice of Hotel Attributes Presented in Travel Agent Brochures. International Journal of Research. Vol. 16. Iss: 1. pp. 65-67

Hyun, S.S. \& Perdue, R. (2010). Previous trip satisfaction, destination images, and probability of future visitation. Tourism Analysis, 15(6), 725-728.

Khutson, B., Stevens, P., Patton, M., \& Thomson, C. (1992). Consumers' expectations for service quality in economy, mid-priced and luxury hotels. Journal of Hospitality and Leisure Marketing, 1(2), 27-43. http://dx.doi.org/10.1300/J150v01n02_03

Kitapci, O., Akdogan, C., and Dortyol, I. T. (2014). The Impact of Service Quality Dimensions on Patient Satisfaction, Repurchase Intentions and Word-of-Mouth Communication in the Public Healthcare Industry. Procedia - Social and Behavioral Sciences, Vol. 148. Pp. 161-169.

Liat, C. B., Mansori, S., Huei, C. T. (2014). The Associations Between Service Quality, Corporate Image, Customer Satisfaction, and Loyalty: Evidence From the Malaysian Hotel Industry. Journal of Hospitality Marketing \& Management Vol. 23. Iss. 3. pp. 314-326.

Mei, A.W.O., Dean, A.M., \& White, C.J. (1999). Analyzing service quality in the hospitality industry. Managing Service Quality, 9(2), 136-143. http://dx.doi.org/10.1108/09604529910257920

Muchtar, R. (2008). Prospek Pengembangan Bisnis Pariwisata di Kota Bandung. Paper Presentation, Unpar.

Nguyen, H.M., Nguyen, T.H., Phan, C.A., Matsui, Y. (2015). Service Quality and Customer Satisfaction: A Case Study of Hotel Industry in Vietnam. Asian Social Science. Vol. 11. No. 10.

Shahril, A.M., Aziz, Y.A., Othman, M., Bojei, J. (2015). Relationship between the Star and the Hotel Service Guarantees Customer Satisfaction. International Journal of Economics and Finance. Vol. 7. No. 4. 
Stevens, P., Knutson, B., Patton, M. (1995). DINESERV: A Toll for Measuring Service Quality in Restaurant, Cornell Hotel Restaurant Administration Quarterly, Vol. 36, pp. 56- 60

Tefera, O., Govender, K. (2015). Hotel Grading, Service Quality, Satisfaction and Loyalty Proposing a Theoritical Model and Relationship. African Journal of Hospitality, Tourism and Leisure. Vol. 4 Iss: Special Edition.

Tussyadiah, L. P. (2016). Factors of satisfaction and intention to use peer-to-peer accommodation. Internation Journal of Hospitality Management. Vol. 55. Pp. 70-80.

Whitelaw, P.A., and Jago, L. (2009). Understanding the Key Elements of Star Ratings in Accomodation. Gold Coast, Queensland: CRC. 